\title{
Barresī-ye tațbīqī-ye sāHtār-e dāstān-e kūtāh. Tehrān, Dānešgāh-e Tehrān, 1384/2005, 168 p., biblogr., index. [Analyse comparée de la structure de la nouvelle]
}

\section{Hosseyn Mirzaï}

\section{(2) OpenEdition}

Journals

Édition électronique

URL : http://journals.openedition.org/abstractairanica/21441

DOI : 10.4000/abstractairanica.21441

ISSN : 1961-960X

Éditeur :

CNRS (UMR 7528 Mondes iraniens et indiens), Éditions de l'IFRI

Édition imprimée

Date de publication : 15 mai 2007

ISSN : 0240-8910

Référence électronique

Hosseyn Mirzaï, « Barresī-ye tațbìqi-ye sāhtārr-e dāstān-e kūtāh. Tehrān, Dānešgāh-e Tehrān, 1384/2005,

168 p., biblogr., index. [Analyse comparée de la structure de la nouvelle] », Abstracta Iranica [En ligne],

Volume 28 | 2007, document 364, mis en ligne le 18 septembre 2007, consulté le 25 septembre 2020

URL : http://journals.openedition.org/abstractairanica/21441 ; DOI : https://doi.org/10.4000/

abstractairanica. 21441

Ce document a été généré automatiquement le 25 septembre 2020.

Tous droits réservés 


\title{
Barresī-ye taṭbīqi-ye sā kūtāh. Tehrān, Dānešgāh-e Tehrān, 1384/2005, 168 p., biblogr., index. [Analyse comparée de la structure de la nouvelle]
}

\author{
Hosseyn Mirzaï
}

1 Petit volume d'une grande utilité pour la littérature persane contemporaine, l'ouvrage de Mme Dādvar jette la base d'une étude comparative entre « la nouvelle » naissant en Iran et vivant depuis presque un siècle et demi dans certains pays de lettres.

2 Il est composé de trois parties: genèse de la Nouvelle dans l'histoire littéraire, morphologie et spécificités de sa création.

3 L'étude a servi de prétexte à l'A. pour montrer clairement le statut de ce genre littéraire en Iran et sa place parmi les autres, dans la littérature persane.

4 La qualité comparative du travail se dégageant dans la bibliographie utilisée aide à la compréhension de ce genre qui s'est peu à peu enraciné en Iran.

INDEX

Thèmes : 11.1.2. Littérature persane moderne 
AUTEURS

HOSSEYN MIRZAII

Université de Téhéran 